\title{
ADSORPTION OF GLYPHOSATE IN A FOREST SOIL: A STUDY USING MÖSSBAUER AND FT-IR SPECTROSCOPY
}

Luís Otávio de B. Benetoli, Henrique de Santana, Cristine E. A. Carneiro e Dimas A. M. Zaia*

Departamento de Química, Centro de Ciências Exatas, Universidade Estadual de Londrina, 86051-990 Londrina - PR, Brasil

Ailton S. Ferreira e Andrea Paesano Jr.

Departamento de Física, Centro de Ciências Exatas, Universidade Estadual de Maringá, 87020-900 Maringá - PR, Brasil

Cássia Thaïs B. V. Zaia

Departamento de Ciências Fisiológicas, Centro de Ciências Biológicas, Universidade Estadual de Londrina, 86051-990 Londrina - PR, Brasil

Recebido em 28/5/09; aceito em 25/11/09; publicado na web em 23/3/10

\begin{abstract}
We studied the adsorption of glyphosate (GPS) onto soil mineral particles, using FT-IR and Mössbauer spectroscopy. From IR measurements for samples collected under native vegetation of a forest reserve, bands at 1632 and $1407 \mathrm{~cm}^{-1}$ could be attributed to the interaction between the carboxylic group of GPS and structural $\mathrm{Al}^{3+}$ and $\mathrm{Fe}^{3+}$ on the surface of mineral particles; bands at 1075 and $1000 \mathrm{~cm}^{-1}$ were observed only for cultivated soil. Mössbauer spectra for these soils were definitely fitted using a broad central doublet in addition to the magnetic component. This multiple quadrupolar component may be attributed to all non-magnetic $\mathrm{Fe}^{3+}$ contributions, including that of the GPS/Fe ${ }^{3+}$ complex.
\end{abstract}

Keywords: herbicides; metals; soil.

\section{INTRODUCTION}

Glyphosate (GPS) (Figure 1) is among the most widely used herbicides in Paraná State, Brazil. ${ }^{1}$ GPS has molecular formula $\mathrm{C}_{3} \mathrm{H}_{8} \mathrm{NO}_{5} \mathrm{P}$ $\left(\mathrm{M}=169.1 \mathrm{~g} \mathrm{~mol}^{-1}\right)$, being soluble in water $\left(12 \mathrm{~g} \mathrm{~L}^{-1}\right.$ at $\left.25^{\circ} \mathrm{C}\right)$ and almost insoluble in organic solvents (acetone, ethanol, etc). The fusion point of GPS is $200{ }^{\circ} \mathrm{C}$ and it is stable in the presence of light even at tempertature of $60^{\circ} \mathrm{C} .{ }^{2}$ Figure 1 shows the pKa-values for GPS. ${ }^{2}$
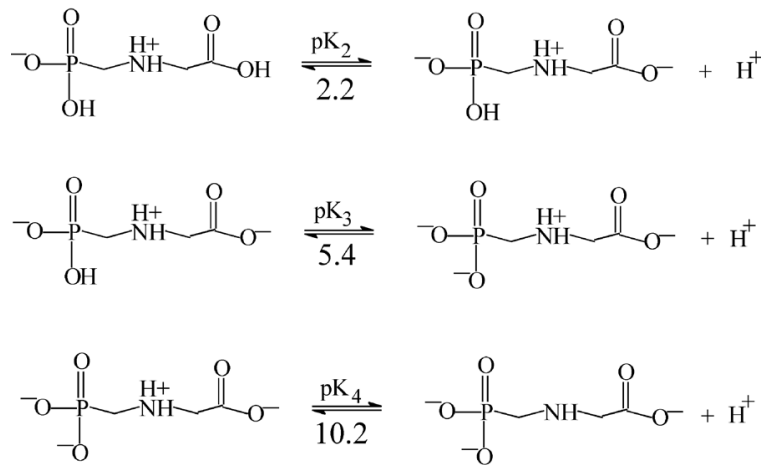

Figure 1. Structural representation of glyphosate and the acid dissociation constants are: for first phosphonic pKa2 $=2.2$; for second phosphonic $p K a 3$ $=5.4$ and for amine $\mathrm{pKa} 4=10.2$

There are several studies showing that the retention of GPS in soils depends on the cation exchange capacity $(\mathrm{CEC})^{3}$ of the occurring minerals, clay content, ${ }^{3}$ organic matter, ${ }^{5-7}$ and iron and aluminum oxides. ${ }^{8-13}$ However, there is no agreement about the most important factors that control the adsorption of GPS.

The interaction of GPS and cation metals/clays/soils has been studied by several authors, and, as reviewed by Toni et al. ${ }^{14}$ the phosphonate group of GPS is always involved, as in some cases also do amine and carboxylic groups. If the concentration of organic matter (OM) in the

*e-mail: damzaia@uel.br soil system is not high, GPS interacts with metal cations mainly on the surface of soil minerals. ${ }^{14}$ Because GPS remains as an anionic charged molecular structure in soils it tends to be more efficiently adsorbed on the surface of positively charged mineral particles than any other neutral or positively charged chemical. ${ }^{611}$ However, this interaction of GPS and surface metal cations can be the cause of many reported environmental problems. Zhou et al. ${ }^{15}$ and Wang et al. ${ }^{16}$ observed that GPS influences decreasing the adsorption of $\mathrm{Cd}$ and $\mathrm{Zn}$ by soils, respectively. Barrett and $\mathrm{McBride}^{7}$ showed that the application of commercial Roundup ${ }^{\circledR}$ (a commercial herbicide based on GPS as active chemical principle) spray to long-contaminated soils containing relatively high concentrations of heavy metals and phosphate resulted in significant increases in of $\mathrm{Cu}, \mathrm{Zn}, \mathrm{Al}, \mathrm{Ni}, \mathrm{P}, \mathrm{Si}$ and As leachings, down trough the soil column or by runoff water. However, no significant leaching was observed in soils with normal background of heavy metals and P. The interaction of GPS and metal cations to form strongly bound chemical complexes can explain the decrease of losses of GPS or metals by runoff water. ${ }^{17}$ Another consequence caused because by the interaction between GPS and metals is that the formed product leads to a decrease of the uptake of metals by plants or antagonize the herbicide action of GPS..$^{18,19}$ On the other hand, Tsui et al. ${ }^{20}$ showed that GPS and its commercial formulations can control the toxicity as well as the bioavailability of heavy metals in aquatic ecosystems. According to Carter et al. ${ }^{21}$ no GPS and tillage interactions is observed.

In the present paper, we studied the adsorptive retention of GPS by pedo-materials from an agriculture cultivated and a soil under native forest vegetation using FT-IR and Mössbauer spectroscopy and cyclic voltammetry. It should be pointed out that as far as we know, there is no paper dealing with the problem of adsorption of GPS in soils using Mössbauer spectroscopy.

\section{EXPERIMENTAL}

\section{Materials}

All reagents used for soil characterization, adsorption of glypho- 
sate in soils, preparation of $\mathrm{GPS} / \mathrm{Fe}^{3+}$ complex and $\mathrm{KBr}$ were of analytical grade.

\section{Glyphosate (GPS)}

Figure 1 shows the chemical structure representation of glyphosate and the corresponding acid dissociation constants.

\section{Soil samples collection}

Both sampled soils were classified as Haplorthox. X-ray analysis of the soils showed the following minerals: kaolinite, gibbsite, and vermiculite. Kaolinite is the mineral with the highest concentration. ${ }^{22}$ Earlier studies showed that the aluminous hematite in this soil has putatively the average formula $\left(\mathrm{Fe}_{1.59} \mathrm{Al}_{0.41}\right) \mathrm{O}_{3}$ and the following iron oxides are found: 0.5 mass $\%$ of goethite, 11.4 mass $\%$ of hematite and 4.4 mass $\%$ of maghemite. ${ }^{23}$

\section{Soils under a native forest reserve}

Soil samples weighing about $2.0 \mathrm{~kg}$ were collected from two soil profiles under native forest vegetation located on the campus of Universidade Estadual de Londrina, PR (Brazil) at two different points, $\mathrm{P}_{0}$ and $\mathrm{P}_{2}$, in depths of 0-32, 32-74, 74-104, 104-155 and 155-200 $\mathrm{cm}$ for $\mathrm{P}_{0}$, and 2-37, 37-65, 65-105, 105-153 and 153-200 $\mathrm{cm}$ for $\mathrm{P}_{2}$, in March and June of 2004. It was collected one sample from each depth. Soil samples were oven-dried at $40{ }^{\circ} \mathrm{C}$ for $24 \mathrm{~h}$, crushed, and sieved with a $2 \mathrm{~mm}$ sieve.

\section{Soils from an agriculture managed area}

The area farm belongs to the Universidade Estadual de Londrina and it is $2.0 \mathrm{~km}$ far from the forest reserve. In 2004, the correction of $\mathrm{pH}$ and fertilization of the soil was done with $2.0 \times 10^{3} \mathrm{~kg}$ of $\mathrm{CaCO}_{3}$ $\mathrm{ha}^{-1}$ and $50 \mathrm{~kg}$ of $\mathrm{P}_{2} \mathrm{O}_{5}$ ha $^{-1}$, respectively. Soils samples were collected at depths of 0-20, 0-32 and 20-70 cm. It was collected one sample from each depth. The samples were oven-dried at $40{ }^{\circ} \mathrm{C}$ for $24 \mathrm{~h}$, crushed, and sieved with a $2 \mathrm{~mm}$ sieve.

\section{Laboratory methods}

\section{Soil characterization}

Total phosphorus $\mathrm{P}$ (total), available phosphorus $\mathrm{P}$ (available) and $\mathrm{pH}$ were determined for all soil samples by the standard methods described by IAPAR and EMBRAPA. ${ }^{24,25}$ Maximum sorption capacity was measured as described by Alvarez et al. ${ }^{26}$ Results are presented in Tables 1 and 2.

\section{Adsorption of glyphosate (GPS) in soils}

Each soil sample was prepared as follows: to two different sets of four tubes $(15 \mathrm{~mL})$ containing $1.00 \mathrm{~g}$ of soil were added $10.0 \mathrm{~mL}$ of $0.10 \mathrm{~mol} \mathrm{~L}^{-1} \mathrm{KCl}$ and $10.0 \mathrm{~mL}$ of a saturated solution of GPS dissolved in $0.10 \mathrm{~mol} \mathrm{~L}^{-1} \mathrm{KCl}$. The tubes were tumbled for $24 \mathrm{~h}$ and then spun for $15 \mathrm{~min}$ at 2,000 rpm. The aqueous phase was used to obtain the cyclic voltammograms and the solid phase was oven-dried at $40{ }^{\circ} \mathrm{C}$ for $24 \mathrm{~h}$. The FT-IR and Mössbauer spectra of the solids were recorded as described below.

\section{Preparation of $\mathrm{GPS} / \mathrm{Fe}^{3+}$ complex}

A precipitate was obtained when equal volumes $(100 \mathrm{~mL})$ of 0.010 mol $\mathrm{L}^{-1}$ of $\mathrm{GPS}$ and $\mathrm{FeCl}_{3} \cdot 6 \mathrm{H}_{2} \mathrm{O}$ solutions were mixed. The solution was then spun for $15 \mathrm{~min}$ at $2,000 \mathrm{rpm}$. The aqueous phase was discarded and the solid phase was oven-dried at $40{ }^{\circ} \mathrm{C}$ for $24 \mathrm{~h}$. The FT-IR and Mössbauer spectra of the solids were recorded as described below.

Infrared-FT (FT-IR) spectrophotometry of soils

IR spectra were recorded with a FT-IR 8300 Shimadzu spectropho- tometer using pressed $\mathrm{KBr}$ disks, at a spectral resolution of $4 \mathrm{~cm}^{-1}$, with 80 scans and a spectral width ranging from 400 to $4000 \mathrm{~cm}^{-1}$. About 10 $\mathrm{mg}$ of soil sample and $200 \mathrm{mg}$ of $\mathrm{KBr}$ were weighed and ground in an agate mortar with a pestle until a homogeneous mixture was obtained. FT-IR spectra were analyzed using the Origin program (5.0, 2001).

\section{Mössbauer spectroscopy (MS) of soils and GPS/Fe ${ }^{3+}$ samples}

Mössbauer spectroscopy (MS) is a characterization technique that allows identifying the chemical environment and the magnetic state of iron by determining the hyperfine interactions on a nuclear probe present in natural iron (i.e., ${ }^{57} \mathrm{Fe}$ ). It is particularly suitable for the determination of the iron valence (in this case, the ratio $\mathrm{Fe}^{2+} / \mathrm{Fe}^{3+}$ ) and extensively applied in mineralogical studies. ${ }^{27,28}$ Mössbauer spectroscopy measurements were performed in the transmission geometry using an assembled set of nuclear instrument modules, operating in the constant acceleration mode. A beam of $\gamma$-rays were provided by a ${ }^{57} \mathrm{Co}(\mathrm{Rh})$ source. A liquid nitrogen/helium cryostat (Janis - SVT400) was used for low-temperature measurements. The Mössbauer spectra were analyzed with a non-linear least-square fitting routine with Lorentzian line shapes. Hyperfine magnetic field distributions were occasionally built as of histograms with a fixed linewidth $(\Gamma)$. All isomer shift (IS) data given in this paper are quoted relative to $\alpha-\mathrm{Fe}$.

\section{Cyclic voltammograms}

The electrochemical equipment used was a potentiostat-galvanostat MQPG-01 Microquímica coupled to a personal computer. Cyclic voltammograms were performed in a single-compartment cell fitted with a Pt plate $(99.99 \%)$ as a working electrode, a large Pt sheet as an auxiliary electrode, and an $\mathrm{Ag} / \mathrm{AgCl}$ reference electrode. Continuous cycle voltammograms were obtained from -0.2 to $+0.8 \mathrm{~V}$ for GPS in $0.10 \mathrm{~mol} \mathrm{~L}^{-1} \mathrm{KCl}$, from -0.2 to $+1.2 \mathrm{~V}$ for soil in $0.10 \mathrm{~mol} \mathrm{~L}^{-1} \mathrm{KCl}$, and from -0.6 to $+1.0 \mathrm{~V}$ for the saturated solution of GPS in 0.10 mol L-1 $\mathrm{KCl}$ plus soil and the GPS/Fe ${ }^{3+}$ complex in $0.10 \mathrm{~mol} \mathrm{~L}^{-1} \mathrm{KCl}$.

\section{RESULTS AND DISCUSSION}

Figure 2 shows the FT-IR spectra of solid GPS, GPS/Fe ${ }^{3+}$ complex, GPS adsorbed onto forest reserve soil, and GPS adsorbed onto soil particles of a farm soil in the a Londrina area. The FT-IR spectrum of solid GPS (Figure 2, spectra a) shows several bands. Some of them can be attributed to: $3017 \mathrm{~cm}^{-1} / \mathrm{NH}_{2}^{+}, 2837 \mathrm{~cm}^{-1} /$ group $\mathrm{CH}_{2} ; 2733 \mathrm{~cm}^{-1} /$ group $\mathrm{COOH} ; 2532 \mathrm{~cm}^{-1} / \beta \mathrm{H}$ of $\mathrm{COOH} ; 1733-1715 \mathrm{~cm}^{-1} / \beta \mathrm{H}$ of $\mathrm{COOH} ; 1421$ $\mathrm{cm}^{-1} / v(\mathrm{C}-\mathrm{OH}) ; 1271 \mathrm{~cm}^{-1} / v(\mathrm{P}=\mathrm{O}) ; 1222 \mathrm{~cm}^{-1} / v(\mathrm{P}-\mathrm{OH}) ; 1203 \mathrm{~cm}^{-1} / v$ $(\mathrm{C}-\mathrm{OH}) ; 1160 \mathrm{~cm}^{-1} / \mathrm{v}(\mathrm{P}-\mathrm{OH}) ; 1093 \mathrm{~cm}^{-1} / \nu_{\text {asym }}\left(\mathrm{P}-\mathrm{O}^{-}\right)$of group $\mathrm{PO}_{2}(\mathrm{OH})^{-}$ and $999 \mathrm{~cm}^{-1} / \mathrm{v}(\mathrm{P}-\mathrm{OH})$. The following bands in the FT-IR spectrum of complex GPS/Fe $/ \mathrm{Fe}^{3+}$ (Figure 2, spectra b) were attributed to $1404 \mathrm{~cm}^{-1} / \mathrm{sym}$ stretch $\mathrm{C}-\mathrm{O}$ of COO-Fe group; $1320 \mathrm{~cm}^{-1} / \mathrm{v}\left(\mathrm{BCH}_{2}\right)$ and the broad band at $1077 \mathrm{~cm}^{-1} / v_{\text {asym }}\left(\mathrm{P}-\mathrm{O}^{-}\right) .{ }^{29-31}$ The adsorption of GPS onto soils of Paraná State was studied by da Cruz et $a l .{ }^{4}$ and de Santana et al..$^{32}$ The FT-IR spectrum of GPS adsorbed onto the soil of a Londrina area farm (Figure 2, spectra d) shows two new bands at 1075 and $1100 \mathrm{~cm}^{-1}$. These bands have been attributed to the interaction between the phosphonate group of GPS (Figure 1) and metals $\left(\mathrm{Fe}^{3+}, \mathrm{Al}^{3+}\right)$ in soils. ${ }^{32}$ The bands at 1632 and 1407 $\mathrm{cm}^{-1}$ were attributed to the interaction between the carbonate group of GPS (Figure 1) and Fe ${ }^{3+}$ in soils. ${ }^{29}$ As shown in Figure 1S, supplementary material, the complex GPS/Fe ${ }^{3+}$ is not electroactive, because increasing concentrations of GPS causes a decrease in current due to decreasing concentration of $\mathrm{Fe}^{3+}$. It should be pointed out that Londrina area soils are rich in $\mathrm{Fe}^{3+}$. However, the FT-IR spectrum of GPS adsorbed onto forest reserve soil did not show the bands between phosphonate group of GPS (Figure 1) and metals $\left(\mathrm{Fe}^{3+}, \mathrm{Al}^{3+}\right)$ (Figure 2, spectra c). The FT-IR spectra of GPS as well as the complex GPS/Fe ${ }^{3+}$ adsorbed onto the farm and forest reserve soils showed a band in the region of 1632 and 1407 
$\mathrm{cm}^{-1}$ (Figures 2, 3). GPS adsorption is low in Londrina soil as seen later on, and $\mathrm{Fe}^{3+}$ and $\mathrm{Al}^{3+}$ are the two metals that form the strongest chelates with GPS,${ }^{33}$ that may indicate that these absorption bands in the forest soil spectrum are due to $\mathrm{Fe}$ - and $\mathrm{Al}$-complexes.
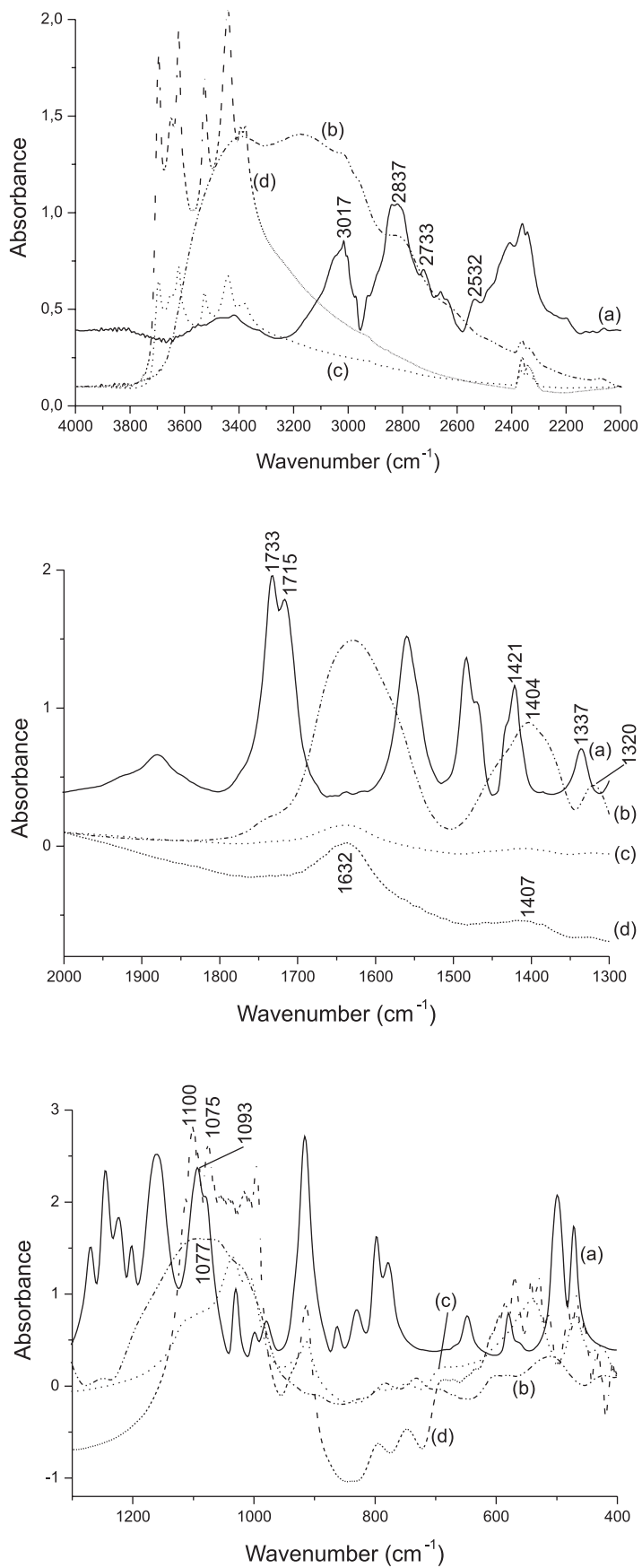

Figure 2. FT-IR spectra a) solid glyphosate, b) glyphosate/Fe ${ }^{3+}$ complex (a solid was obtained after the mixture of equal volumes of $0.010 \mathrm{~mol} \mathrm{~L}^{-1}$ of glyphosate and $\mathrm{FeCl}_{3} \cdot 6 \mathrm{H}_{2} \mathrm{O}$ ), (c) forest reserve soil and (d) from Londrina area farm soil samples. The soil samples were tumbled for $24 \mathrm{~h}$ with saturated glyphosate solution dissolved in $\mathrm{KCl} 0.10 \mathrm{~mol} \mathrm{~L}^{-1}$. All samples were spun for 15 min at 2,000 rpm, the aqueous phases were discharged and the solids were dried in oven at $40^{\circ} \mathrm{C}$ for $24 \mathrm{~h}$

Other authors have also studied the interaction between GPS (Figure 1) and metals, ${ }^{19,31,34-36}$ minerals/clays ${ }^{37-45}$ and soils. ${ }^{4-7,11-13,16,32,42}$ They found that the GPS phosphonate group interacts with metals, and in some cases, amine and/or carboxylic groups also interact with

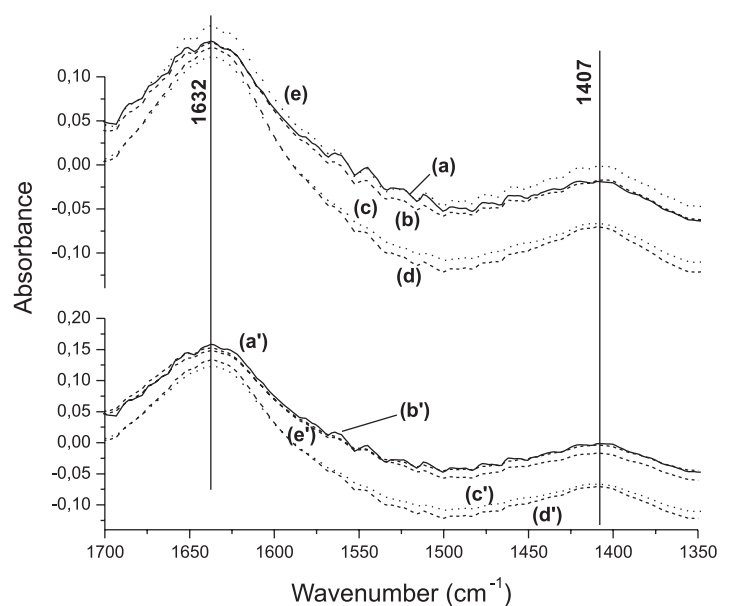

Figure 3. FT-IR spectra $P_{2}$ samples were collected at several depths: March (a) 2-37, (b) 37-65, (c) 65-105, (d) 105-153, (e) 153-200 cm and June ( ${ }^{\prime}$ ') 2-37, (b') 37-65, (c') 65-105, (d') 105-153, (e') 153-200 cm. All samples were tumbled for $24 \mathrm{~h}$ with saturated glyphosate solution dissolved in $\mathrm{KCl} 0.10$ mol $L^{-1}$. Afterwards, they were spun for $15 \mathrm{~min}$ at 2,000 rpm. The aqueous phases were discharged and the solids were dried in oven at $40^{\circ} \mathrm{C}$ for $24 \mathrm{~h}$

metals. Thus, forest reserve soil samples should also show an FT-IR band due to the interaction of metals $\left(\mathrm{Fe}^{3+}, \mathrm{Al}^{3+}\right)$ with the phosphonate group of GPS (Figure 1). However, the amount of total-P in the forest reserve soil is much higher than in the soil of the farm area (Table 1). The lower amount of total-P in this farm soil can be explained in this way: it was added $21.8 \mathrm{~kg}$ of $\mathrm{P}\left(50.0 \mathrm{~kg} \mathrm{P}_{2} \mathrm{O}_{5}\right) \mathrm{ha}^{-1}$ and the intake of $\mathrm{P}$ by soybean plant was about $20.0 \mathrm{~kg}$ of $\mathrm{P}\left(45.9 \mathrm{~kg} \mathrm{P}_{2} \mathrm{O}_{5}\right) / \mathrm{ha},{ }^{46}$ being left in the soil $1.8 \mathrm{~kg}$ of $\mathrm{P}\left(4.1 \mathrm{~kg} \mathrm{P}_{2} \mathrm{O}_{5}\right) \mathrm{ha}^{-1}$. Thus almost all added $\mathrm{P}$ was used for the soybean plant. But, $\mathrm{P}$ (available) in the area farm soil is much bigger than in the forest reserve soil (Table 1). It should also be pointed out that even for a forest soil sample, this concentration of $\mathrm{P}$ (available) (Table 1) is lower than that obtained by other authors $\left(0.77-2.72 \mathrm{mg} \mathrm{kg}^{-1}\right)$ for other forest evironments. ${ }^{47-49}$ Table 2 shows the maximum sorption capacity (MSC) of $\mathrm{P}$ and $\mathrm{pH}$ in the soils of forest reserve and area farm. As expected for all soils, MSC increase with an increase of depth and MSC of the soil of forest reserve is lower than in area farm (Table 2). In general, we can say that the soils from forest reserve are more acid than are the soils from the farm area (Table2). The lower concentrations of $\mathrm{P}$ total, the higher concentrations of $\mathrm{P}$ available, higher $\mathrm{pH}$ and the higher values of MSC in the soils of farm area when compared to the soils of forest reserve could be used to explain why the bands at 1075 and $1100 \mathrm{~cm}^{-1}$ were not observed. Therefore, GPS may not be adsorbed by metals $\left(\mathrm{Fe}^{3+}, \mathrm{Al}^{3+}\right)$ in forest reserve soil because the adsorption sites are occupied by phosphate, and as observed by Mamy and Barriuso, ${ }^{11}$ Wang et al. ${ }^{12}$ and Gimsing et al. ${ }^{13}$ pre-sorbed phosphate on soils suppresses adsorption of GPS.

A study of the adsorption of GPS and $\mathrm{PO}_{4}^{3-}$ as well as the GPS/ $\mathrm{Fe}^{3+}$ and $\mathrm{PO}_{4}^{3-} / \mathrm{Fe}^{3+}$ complexes in soils of the Londrina area farm and forest reserve was undertaken by Mössbauer spectroscopy to better understand this process. However, it should be pointed out that Mössbauer data would provide more insights about the structure of iron-bearing minerals. Because the (super) paramagnetic doublets of iron oxides would normally tend to mask any minor signal due to iron-organic compounds.

Figure 2S, supplementary material, shows the RT Mössbauer spectrum for the farm soil sample. The spectrum shows a magnetic pattern with broadened and asymmetric lines superimposed to a quadrupolar doublet contribution. All other samples measured within the same velocity range show similar hyperfine magnetic distributions (see figure inset) with the most probable hyperfine field around 49.6 
Table 1. Concentration of phosphorus (total) and phosphorus (available) in soil samples from forest reserve and a farm located at Universidade Estadual de Londrina

\begin{tabular}{|c|c|c|c|c|c|}
\hline \multicolumn{6}{|c|}{ Samples from forest reserve } \\
\hline \multicolumn{2}{|c|}{ Sample } & \multicolumn{2}{|c|}{$\begin{array}{l}\mathrm{P}(\text { total })^{* * \psi} \\
\mathrm{P}_{2} \mathrm{O}_{5}\left(\mathrm{~g} \mathrm{~kg}^{-1}\right)\end{array}$} & \multicolumn{2}{|c|}{$\begin{array}{c}\mathrm{P}(\text { available }) * * * \psi \\
\mathrm{P}_{2} \mathrm{O}_{5}\left(\mathrm{mg} \mathrm{kg}^{-1}\right)\end{array}$} \\
\hline $\mathrm{P}^{*}$ & Depths $(\mathrm{cm})$ & M & $\mathrm{J}$ & M & $\mathrm{J}$ \\
\hline $\mathrm{P}_{0}$ & $0-32$ & 0.94 & 0.88 & 0.08 & 0.30 \\
\hline $\mathrm{P}_{0}$ & $32-74$ & 0.89 & 0.87 & 0.25 & 0.39 \\
\hline $\mathrm{P}_{0}$ & 74-104 & 1.03 & 0.87 & 0.19 & 0.28 \\
\hline $\mathrm{P}_{0}$ & $104-155$ & 0.86 & 0.81 & 0.48 & 0.41 \\
\hline $\mathrm{P}_{0}$ & $155-200$ & 0.93 & 0.84 & 0.49 & 0.52 \\
\hline $\mathrm{P}_{2}$ & $2-37$ & 0.74 & 0.78 & 0.35 & 0.33 \\
\hline $\mathrm{P}_{2}$ & $37-65$ & 0.82 & 0.80 & 0.41 & 0.82 \\
\hline $\mathrm{P}_{2}$ & $65-105$ & 0.77 & 0.82 & 0.85 & 0.11 \\
\hline $\mathrm{P}_{2}$ & $105-153$ & 0.83 & 0.79 & 0.94 & 1.00 \\
\hline $\mathrm{P}_{2}$ & $153-200$ & 0.78 & 0.89 & 0.67 & 0.76 \\
\hline \multicolumn{6}{|c|}{ Samples from farm } \\
\hline \multicolumn{2}{|c|}{ Depths (cm) } & \multicolumn{2}{|c|}{$\begin{array}{l}\mathrm{P}(\text { total })^{* * \phi} \\
\mathrm{P}_{2} \mathrm{O}_{5}\left(\mathrm{~g} \mathrm{~kg}^{-1}\right)\end{array}$} & \multicolumn{2}{|c|}{$\begin{array}{c}\mathrm{P}(\text { available })^{* * * \phi} \\
\mathrm{P}_{2} \mathrm{O}_{5}\left(\mathrm{mg} \mathrm{kg}^{-1}\right)\end{array}$} \\
\hline \multicolumn{2}{|c|}{$0-20$} & \multicolumn{2}{|c|}{0.088} & \multicolumn{2}{|c|}{12.0} \\
\hline \multicolumn{2}{|c|}{$20-70$} & \multicolumn{2}{|c|}{0.004} & \multicolumn{2}{|c|}{1.50} \\
\hline
\end{tabular}

*P=soil sampling points, $\mathrm{M}=$ March, $\mathrm{J}=\mathrm{J} u n e, * *$ Total phosphorus in $\mathrm{H}_{2} \mathrm{SO}_{4} /$ $\mathrm{H}_{2} \mathrm{O}$ 1:1; ***Available phosphorus in $\mathrm{HCl} 0.05 \mathrm{~mol} \mathrm{~L}^{-1}$ and $\mathrm{H}_{2} \mathrm{SO}_{4} 0.0125$ mol L- ${ }^{-},{ }^{\psi}$ Means of two analyses and ${ }^{\phi}$ Means of three analyses.

Table 2. Maximum sorption capacity and $\mathrm{pH}$ in soil samples from forest reserve and a farm located at Universidade Estadual de Londrina

\begin{tabular}{lcccccc}
\hline \multirow{2}{*}{$*$ Forest reserve } & & & \multicolumn{3}{c}{ Farm } \\
$\mathrm{P}^{*}$ & $\begin{array}{c}\text { Depths } \\
(\mathrm{cm})\end{array}$ & ${ }^{\Delta} \mathrm{pH}$ & $\begin{array}{c}{ }^{\phi} \mathrm{MSC} \\
\left(\mathrm{mg} \mathrm{kg}^{-1}\right)\end{array}$ & $\begin{array}{c}\text { Depths } \\
(\mathrm{cm})\end{array}$ & ${ }^{\Delta} \mathrm{pH}$ & $\begin{array}{c}{ }^{\phi} \mathrm{MSC} \\
\left(\mathrm{mg} \mathrm{kg}^{-1}\right)\end{array}$ \\
\hline $\mathrm{P}_{0}$ & $0-32$ & 4.18 & 1106 & $0-20$ & 6.50 & 1500 \\
$\mathrm{P}_{0}$ & $32-74$ & 4.05 & 1513 & $20-70$ & 4.30 & 3000 \\
$\mathrm{P}_{2}$ & $2-37$ & 5.96 & 789 & - & - & - \\
$\mathrm{P}_{2}$ & $37-65$ & 6.08 & 1039 & - & - & - \\
\hline
\end{tabular}

$* \mathrm{P}=$ soil sampling points, $* *$ Samples of March, ${ }^{\phi} \mathrm{MSC}$ - Maximum sorption capacity sorption, ${ }^{\Delta} \mathrm{pH}$ in $\mathrm{CaCl}_{2} 0.010 \mathrm{~mol} \mathrm{~L}^{-1}$

$\mathrm{T}$ and relative area of $\sim 79 \%$. Both the magnetic (six-line pattern) and non-magnetic (doublet) contributions may be attributed to sometimes poorly crystallized iron oxides usually present in soils such as hematite, maghemite and magnetite. It was not the intention of this work to identify them individually; however, aiming to better define the central part of the spectra, all the samples were further measured at a lower velocity range.

The RT spectrum of GPS adsorbed onto the farm soil obtained in this condition is shown in Figure 2S, supplementary material together with the GPS/ $\mathrm{Fe}^{3+}$ complex pattern. The latter reveals a doublet with poorly resolved lines, as expected for compounds of this chemical nature. As far as we know, no ${ }^{57} \mathrm{Fe}$ Mössbauer spectroscopy characterization of this complex is reported in the scientific literature. A similar pattern (not shown) was found for the $\mathrm{PO}_{4}^{3-} / \mathrm{Fe}^{3+}$ complex sample. On the other hand, in the Londrina area farm soil spectrum (Figure 3Sa, supplementary material), the pair of external lines corresponds to lines 3 and 4 of the magnetic distribution (i.e., the nuclear transitions $|-/+1 / 2>\otimes| \pm 1 / 2>)$. Two additional doublets were used to fit this series of spectra. One of them (i.e., the central one) is attributed to the trivalent iron present in the sample, regardless of the chemical phase. Conceivably, a GPS/Fe ${ }^{3+}$ complex component could be contributing to this non-magnetic subspectrum albeit to a very small degree. The other doublet reveals a minor presence of divalent iron, as expected for this type of soil. The hyperfine parameters and subspectral areas obtained from these and other fits are presented in Table 1S (supplementary material).

To determine the presence of either GPS/Fe ${ }^{3+}$ or $\mathrm{PO}_{4}{ }^{3-} / \mathrm{Fe}^{3+}$ in the soil samples, the samples were also measured at $88 \mathrm{~K}$. Figure $4 \mathrm{~S}$, supplementary material, shows some selected results obtained at this temperature. Both complexes also show doublets (Figure 4S a and b), even though with broadened lines. This could be due to some initial magnetic splitting, as a consequence of the lowered temperature.

Regarding the soil spectra (Figure $4 \mathrm{~S} \mathrm{c}, \mathrm{d}$, and e), there are two outermost and dominant lines that, again, correspond to transitions 3 and 4 of the magnetic contribution, here supposedly originating from both $2^{+}$and $3^{+}$iron valence states. As expected, this subspectral component increased at low temperature as a result of the progressive spin freezing of the superparamagnetic oxide particles inevitably present in soil samples. In addition, there is a remaining non-magnetic spectral portion located between the external lines of the spectra taken at 88 $\mathrm{K}$. In all cases, this spectral portion accounts for only a small percent of the total spectrum area (Table $1 \mathrm{~S}$, supplementary material) and does not show significant differences when spectra of processed and non-processed soils are compared.

However, it is worth pointing out that in spite of the absence of a sharp resolution, an excellent match between the experimental and theoretical curves was achieved when two doublets were used tentatively to fit the very central part of the spectra of GPS- and $\mathrm{PO}_{4}{ }^{3-}$-containing samples. One of the components had IS, QS, and $\Gamma$ constrained to be equal to those found for the respective complex itself (i.e., either $\mathrm{PO}_{4}^{3-} / \mathrm{Fe}^{3+}$ or $\mathrm{GPS} / \mathrm{Fe}^{3+}$ ) at $88 \mathrm{~K}$, while its subspectral area was a free parameter. The hyperfine parameters of the second doublet varied freely.

The fits showed that the relative areas ascribable to either the GPS/ $\mathrm{Fe}^{3+}$ complex (Figure $4 \mathrm{~S}$ c, supplementary material) or the $\mathrm{PO}_{4}^{3-} / \mathrm{Fe}^{3+}$ complex (Figure $4 \mathrm{~S} \mathrm{~d}$ ) are around $1 \%$ of the total spectrum. These subspectral areas could be understood merely as rough approximations since the uncertainties are as large as the fitted values, which demonstrates that the complex concentrations in the processed soils are too low to be unambiguously detected by Mössbauer spectroscopy. Indeed, according to Glass, ${ }^{3}$ Morillo et al.,${ }^{5}$ Prata et al.,${ }^{8}$ Wang et al., ${ }^{12,16}$ da Cruz et al. ${ }^{4}$ and Gimsing et al., ${ }^{13}$ the amount of GPS adsorbed for several soils studied by these authors ranged from 0.02 to $60 \mu \mathrm{mol}$ of GPS/ $\mathrm{g}$ of soil.

Thus, consistent with the considerations above, the spectra of the sample soils were definitely fitted using a single doublet in addition to the magnetic component attributable to all non-magnetic $\mathrm{Fe}^{3+}$ contributions, including that of the GPS/Fe $\mathrm{Fe}^{3+}$ complex.

\section{CONCLUSION}

In summary, FT-IR data showed that the adsorption of GPS onto mineral particles of the forest reserve soil could be occurred through the interaction of the GPS carboxylic group with the metals in soil. The bands of interaction of the phosphonate group of GPS and metals were only observed in the farm soil studied and not with the forest reserve.

Cyclic voltammograms showed that GPS interacts with $\mathrm{Fe}^{3+}$ in solution because the GPS/ $/ \mathrm{Fe}^{3+}$ complex is not electroactive.

Because of the acidic $\mathrm{pH}$, higher concentration o $\mathrm{P}$ (total) and lower concentration of $\mathrm{P}$ (available) of the forest reserve soil, phosphate is adsorbed by $\mathrm{Al}^{3+}$ and $\mathrm{Fe}^{3+}$. Thus, in the forest reserve soil, GPS is not adsorbed by metals $\left(\mathrm{Fe}^{3+}, \mathrm{Al}^{3+}\right)$ through the phosphonate group because adsorption sites in the soil are occupied by phosphate. This is supported by several authors who have shown that phosphate pre-sorbed onto soils does not exchange with GPS.Mössbauer 
spectroscopy showed that the spectra for the processed soils were definitely fitted using a single doublet in addition to the magnetic component. This component may be attributed to all non-magnetic $\mathrm{Fe}^{3+}$ contributions, including that of the GPS/Fe $\mathrm{Fe}^{3+}$ complex. Unfortunately, the amount of GPS adsorbed onto the grain surface of these soil minerals soils was too small to be unambiguously detected by transmission Mössbauer spectroscopy.

\section{SUPPLEMENTARY MATERIAL}

There are 4 figures and 1 table included as supplementary material correspondent to cyclic voltammograms (Figure 1S), several differents Mössbauer spectra (Figures 2S, 3S e 4S) and Mössbauer hyperfine parameters and subspectral areas (Table 1S). These figures and the table are freely available at http://quimicanova.sbq.org.br, as PDF file.

\section{ACKNOWLEDGMENTS}

L. O. B. Benetoli and C. E. A. Carneiro acknowledge fellowship from CNPq. This research was supported by grants from CAPES/PROAP, Fundação Araucária (number 2421), and CNPq (473076/2004).

\section{REFERENCES}

1. http://www.zoonews.com.br, accessed March 2010.

2. de Amarante Jr., O. P.; dos Santos, T. C. R.; Brito, N. M.; Ribeiro, M. L.; Quim. Nova 2002, 25, 589

3. Glass, R. L.; J. Agric. Food Chem. 1987, 35, 497.

4. da Cruz, L. H.; de Santana, H.; Zaia, C. T. B. V.; Zaia, D. A. M.; Braz. Arch. Biol. Technol. 2007, 50, 385.

5. Morillo, E.; Undabeytia, T.; Maqueda, C.; Ramos, A.; Chemosphere 2000, 40, 103 .

6. Dousset, S.; Chauvin, C.; Durlet, P.; Thévenot, M.; Chemosphere 2004 $57,265$.

7. Barrett, K. A.; McBride, M. B.; Soil Sci. Soc. Am. J. 2006, 70, 1882.

8. Prata, F.; Lavorenti, A.; Regitano, J. B.; Tornisielo, V. L.; Rev. Bras. Ciênc. Solo 2000, 24, 947.

9. Gerritse, R. G.; Beltran, J.; Hernadez, F.; Aust. J. Soil Res. 1996, 34, 599.

10. Gimsing, A. L.; Borggaard, O. K.; Bang, M.; Eur. J. Soil Sci. 2004, 55, 183.

11. Mamy, L.; Barriuso, E.; Chemosphere 2005, 61, 844.

12. Wang, Y. J.; Zhou, D. M.; Sun, R. J.; J. Environ. Sci. 2005, 17, 711.

13. Gimsing, A. L.; Szilas, C.; Borggaard, O. K.; Geoderma 2007, 138, 127

14. Toni, L. R. M.; de Santana, H.; Zaia, D. A. M.; Quim. Nova 2006, 29, 829.

15. Zhou, Z.; Wang, Y. J.; Cang, L.; Hao, X. Z.; Luo, X. S.; Chemosphere 2004, 57, 1237.

16. Wang, Y. J.; Zhou, D. M.; Sun, R. J.; Cang, L.; Hao, X. Z.; J. Hazard. Mater. A 2006, 137, 76.

17. Warnemuende, E. A.; Patterson, J. P.; Smith, D. R.; Huang, C.; Soil Till. Res. 2006, 95, 19.

18. Bernards, M. L.; Thelen, K. D.; Penner, D.; Muthukumaran, R. B.; McCracken, J. L.; Weed Sci. 2005, 53, 787.
19. Eker, S.; Ozturk, L.; Yazici, A.; Erenoglu, B.; Romheld, V.; Cakmak, I.; J. Agric. Food Chem. 2006, 54, 10019.

20. Tsui, M. T. K.; Wang, W. X.; Chu, L. M.; Environ. Poll. 2005, 138, 59.

21. Carter, M. R.; Sanderson, J. B.; Holmstrom, D. A.; Ivany, J. A.; DeHaan, K. R.; Soil Till. Res. 2007, 93, 206.

22. Rocha, G. C.; Barros, O. N. F.; Guimarães, M. F.; Semina 1991, 12, 25.

23. Carneiro, C. E. A.; Tese de Doutorado, Universidade Estadual de Londrina, Brasil, 2008

24. IAPAR; Manual de análise química de solo e controle de qualidade, IAPAR: Londrina, 1992.

25. EMBRAPA; Manual de métodos de análises de solo, 2a ed., EMBRAPA: Rio de Janeiro, 1997.

26. Alvarez, V. H.; Novais, R. F.; Dias, L. E.; Oliveira, J. A.; Rev. Bras. Ciênc. Solo 2000, 25, 27.

27. Danon, J. Em Chemical applications of Mössbauer spectroscopy; Goldanskii, V. I.; Herber, R. H., eds.; Academic Press: New York, 1968.

28. Cornell, R. M.; Schwertmann, U.; The iron oxides, Willey-VCH Verlag GmbH \& Co. KGaA: Weinheim, 1996.

29. Miano, T. M.; Piccolo, A.; Celano, G.; Senesi, N.; Sci. Total Environ. 1992, 123/124, 83.

30. Barja, B. C.; Herszage, J.; dos Santos, A. M.; Polyhedron 2001, 20, 1821.

31. Undabeytia, T.; Morillo, E.; Maqueda, C.; J. Agric. Food Chem. 2002, $50,1918$.

32. de Santana, H.; Toni, L. R. M.; Benetoli, L. O. B.; Zaia, C. T. B. V.; Rosa Jr., M.; Zaia D. A. M.; Geoderma 2006, 136, 738.

33. Motekaitis, R. J.; Martell, A. E.; J. Coord. Chem. 1985, 14, 139.

34. Subramaniam, V.; Hoggard, P. E.; J. Agric. Food Chem. 1988, 36, 1326.

35. Undabeytia, T.; Cheshire, M. V.; Mcphail, D.; Chemosphere 1996, 32, 1245.

36. Sheals, J.; Person, P.; Hedman, B.; Inorg. Chem. 2001, 40, 4302

37. McConnell, J. S.; Hossner, L. R.; J. Agric. Food Chem. 1989, 37, 555.

38. Dubbin, W. E.; Sposito, G.; Zavarin, M.; Soil Sci. 2000, 69, 699.

39. Sheals, J.; Sjöberg, S.; Person, P.; Envir. Sci. Tech. 2002, 36, 3090.

40. Didriksen, K.; Stipp, S. L. S.; Geochim Cosmochim. Acta 2003, 67, 3313.

41. Sheals, J.; Granström, M.; Sjöberg, S.; Person, P.; J. Colloid Interface Sci. 2003, 262, 38.

42. Gimsing, A. L.; Borggaard, O. K.; Sestoft, P.; Environ. Sci. Technol. 2004, 38, 1718

43. Wang, Y. J.; Zhou, D. M.; Luo, X. S.; Sun, R. J.; Chen, H. M.; J. Environ. Sci. 2004, 16, 881.

44. Barja, B. C.; dos Santos, A. M.; Environ. Sci. Technol. 2005, 39, 585.

45. Gimsing, A. L.; Borggaard, O. K.; Clays Clay Miner. 2007, 55, 108.

46. Embrapa, Embrapa Soja Tecnologias de produção de soja - região central do Brasil, Embrapa Soja: Londrina, 2007.

47. Fernandes, S. A. P.; Bernoux, M.; Cerri, C. C.; Feigl, B. J.; Piccolo, M. C.; Geoderma 2002, 107, 227.

48. Annan-Afful, E.; Iwashima, N.; Otoo, E.; Owusu-Seyere, E.; Asubonteng, K.O.; Soil Sci. Plant Nutr. 2004, 50, 633.

49. Annan-Afful, E.; Iwashima, N.; Otoo, E.; Asubonteng, K. O.; Kubota, D.; Kamidohzono, A.; Masunaga, T.; Wakatsuki, T.; Soil Sci. Plant Nutr. 2004, 50, 649 . 


\section{ADSORPTION OF GLYPHOSATE IN A FOREST SOIL: A STUDY USING MÖSSBAUER AND FT-IR SPECTROSCOPY}

Luís Otávio de B. Benetoli, Henrique de Santana, Cristine E. A. Carneiro e Dimas A. M. Zaia*

Departamento de Química, Centro de Ciências Exatas, Universidade Estadual de Londrina, 86051-990 Londrina - PR, Brasil Ailton S. Ferreira e Andrea Paesano Jr.

Departamento de Física, Centro de Ciências Exatas, Universidade Estadual de Maringá, 87020-900 Maringá - PR, Brasil Cássia Thaïs B. V. Zaia

Departamento de Ciências Fisiológicas, Centro de Ciências Biológicas, Universidade Estadual de Londrina, 86051-990 Londrina - PR, Brasil

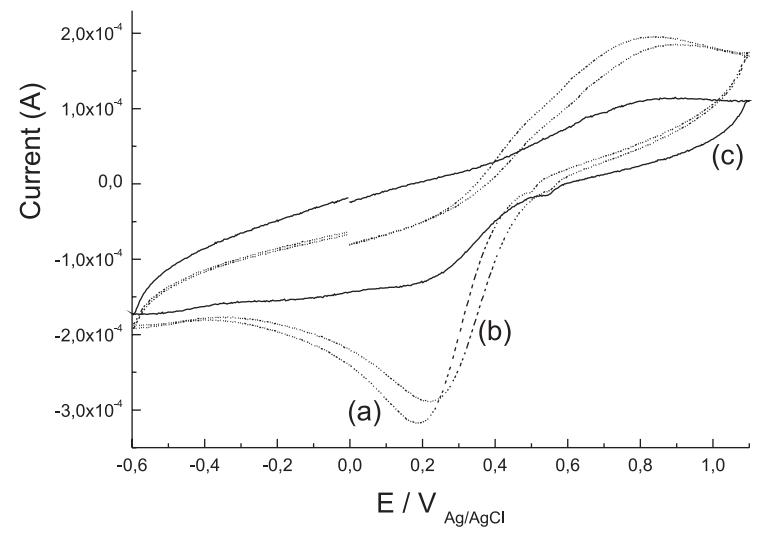

Figure 1S. Cyclic voltammograms (a) $1.0 \times 10^{-4} \mathrm{~mol} \mathrm{~L}^{-1}$ of glyphosate plus 1.0 $x 10^{-2} \mathrm{~mol} \mathrm{~L}^{-1}$ of $\mathrm{FeCl}_{3} .6 \mathrm{H}_{2} \mathrm{O}$ in $\mathrm{KCl} 0.10 \mathrm{~mol} \mathrm{~L}^{-1}$, (b) $1.0 \times 10^{-3} \mathrm{~mol} \mathrm{~L}^{-1}$ of glyphosate plus $1.0 \times 10^{-2} \mathrm{~mol} \mathrm{~L}^{-1} \mathrm{FeCl}_{3} .6 \mathrm{H}_{2} \mathrm{O}$ in $\mathrm{KCl} 0.10 \mathrm{~mol} \mathrm{~L}^{-1}$ and (c) $1.0 \times 10^{-2}$ mol $\mathrm{L}^{-1}$ of glyphosate plus $1.0 \times 10^{-2} \mathrm{~mol} \mathrm{~L} \mathrm{~L}^{-1}$ of $\mathrm{FeCl}_{3} .6 \mathrm{H}_{2} \mathrm{O}$ in $\mathrm{KCl} 0.10 \mathrm{~mol} \mathrm{~L}^{-1}$

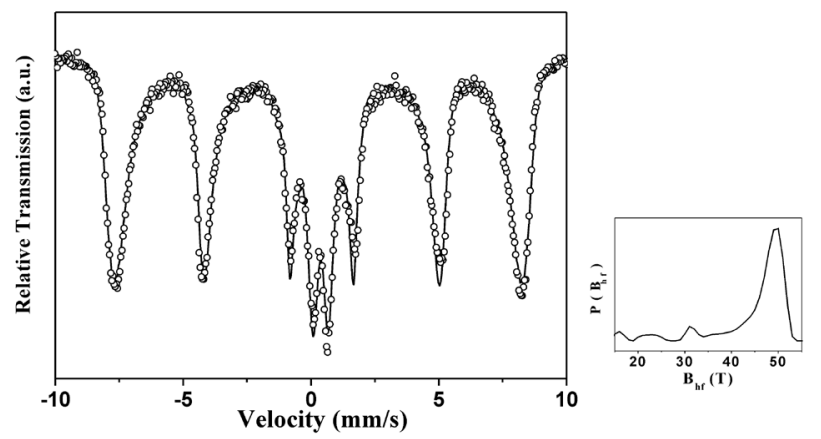

Figure 2S. RT Mössbauer spectrum for the Londrina area farm soil sample without adsorbed GPS. The insert shows the hyperfine magnetic field distribution 


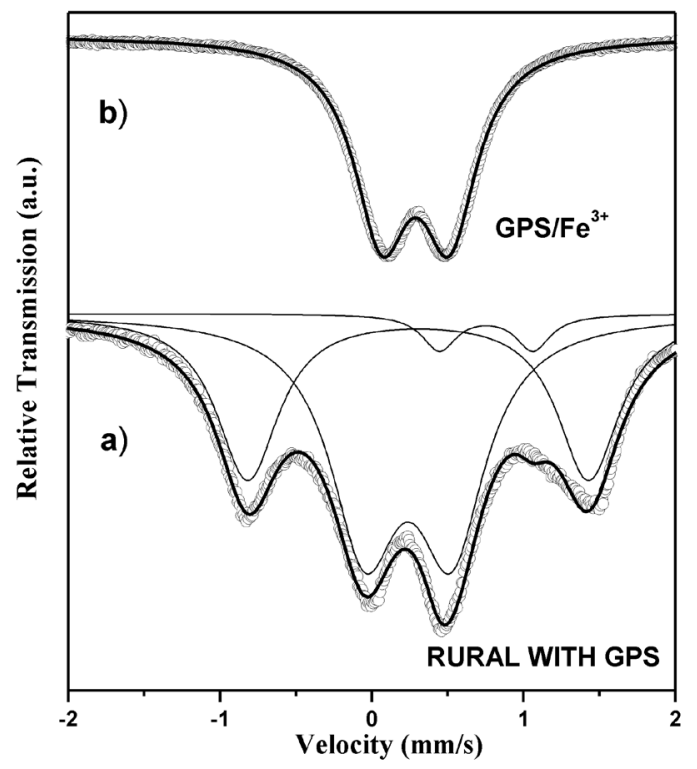

Figure 3S. Mössbauer spectra taken at RT for GPS adsorbed onto Londrina area farm soil (a) and GPS/Fe $e^{3+}$ complex (b) samples. The farm soil sample was tumbled for $24 \mathrm{~h}$ with satured glyphosate solution dissolved in $\mathrm{KCl} 0.10$ $\mathrm{mol}^{-1}$. The sample spun for $15 \mathrm{~min}$ at 2,000 rpm, the aqueous phase was discharged and solid phase was dried in oven at $40^{\circ} \mathrm{C}$ for $24 \mathrm{~h}$

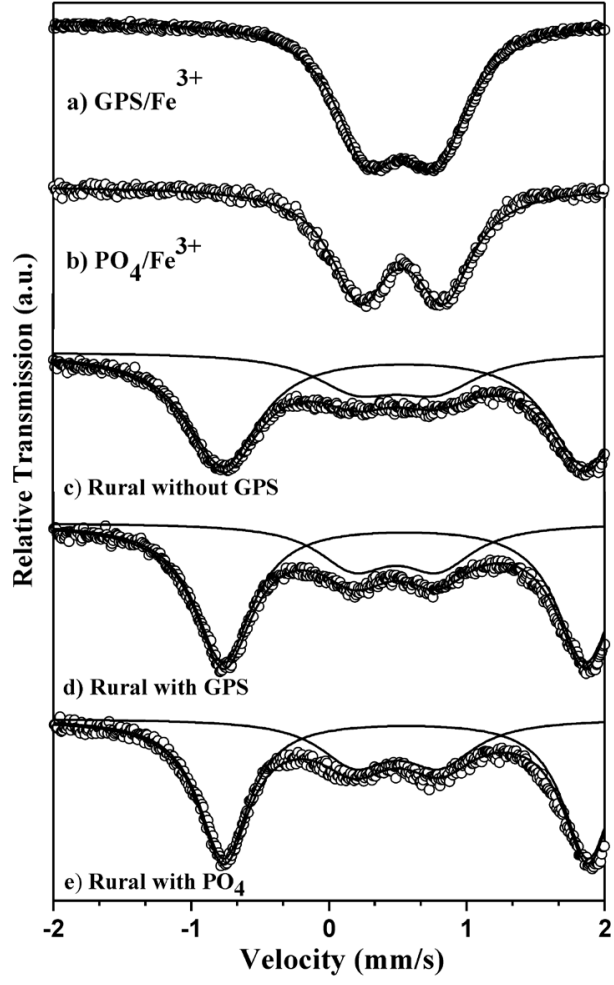

Figure 4S. Mössbauer spectra taken at $88 \mathrm{~K}$ for the $\mathrm{GPS} / \mathrm{Fe}^{3+}$ (a) and $\mathrm{PO}_{4}^{3-}$ $\mathrm{Fe}^{3+}(b)$ complexes, and farm soil samples without Gly (c), with GPS (d), and with $\mathrm{PO}_{4}^{3-}(e)$. Farm soil samples were tumbled for $24 \mathrm{~h}$ with either satured $\mathrm{GPS}$ or $\mathrm{PO}_{4}^{3-}$ solution dissolved in $\mathrm{KCl} 0.10 \mathrm{~mol} \mathrm{~L}^{-1}$. All samples were spun for $15 \mathrm{~min}$ at 2,000 rpm, the aqueous phases were discharged and the solids were dried in oven at $40^{\circ} \mathrm{C}$ for $24 \mathrm{~h}$ 
Table 1S. Mössbauer hyperfine parameters and subspectral areas for the complexes and soil samples

\begin{tabular}{|c|c|c|c|c|c|c|c|}
\hline Sample & Temperature & Subspectrum & $\mathrm{IS}^{\mathrm{a}}(\mathrm{mm} / \mathrm{s})$ & $\mathrm{QS}(\mathrm{mm} / \mathrm{s})$ & $\mathrm{B}_{\mathrm{hf}}^{\mathrm{b}}(\mathrm{T})$ & $\Gamma(\mathrm{mm} / \mathrm{s})$ & $\operatorname{Area}^{c}(\%)$ \\
\hline \multirow{6}{*}{ Farm soil without GPS } & \multirow{3}{*}{$300 \mathrm{~K}$} & Magn. Dist. & 0.35 & 0.13 & 47.7 & 0.50 & 79.7 \\
\hline & & Doublet $\left(\mathrm{Fe}^{3+}\right)$ & 0.38 & 0.60 & - & 0.53 & 18.7 \\
\hline & & Doublet $\left(\mathrm{Fe}^{2+}\right)$ & 0.86 & 0.64 & - & 0.27 & 1.6 \\
\hline & \multirow{3}{*}{$88 \mathrm{~K}$} & Magn. Compn. ${ }^{\mathrm{d}}$ & 0.54 & - & - & 0.64 & 94.2 \\
\hline & & Doublet $\left(\mathrm{Fe}^{3+}\right)$ & 0.49 & 0.57 & - & 0.75 & 5.8 \\
\hline & & Magnetic Dist. & 0.41 & 0.13 & 47.7 & 0.49 & 79.3 \\
\hline \multirow{4}{*}{ Farm soil with GPS } & \multirow[t]{2}{*}{$300 \mathrm{~K}$} & Doublet $\left(\mathrm{Fe}^{3+}\right)$ & 0.38 & 0.61 & - & 0.51 & 19.1 \\
\hline & & Doublet $\left(\mathrm{Fe}^{2+}\right)$ & 0.86 & 0.61 & - & 0.27 & 1.6 \\
\hline & \multirow{3}{*}{$88 \mathrm{~K}$} & Magn. Compn ${ }^{\mathrm{d}}$ & 0.54 & - & - & 0.50 & 93.9 \\
\hline & & Doublet $\left(\mathrm{Fe}^{3+}\right)$ & 0.49 & 0.62 & - & 0.61 & 6.1 \\
\hline \multirow{6}{*}{ Farm soil with $\mathrm{PO}_{4}$} & & Magnetic Dist. & 0.36 & 0.11 & 46.9 & 0.46 & 77.8 \\
\hline & \multirow[t]{2}{*}{$300 \mathrm{~K}$} & Doublet $\left(\mathrm{Fe}^{3+}\right)$ & 0.37 & 0.60 & - & 0.49 & 21.2 \\
\hline & & Doublet $\left(\mathrm{Fe}^{2+}\right)$ & 0.83 & 0.70 & - & 0.36 & 1.0 \\
\hline & \multirow{3}{*}{$88 \mathrm{~K}$} & Magn. Compn ${ }^{d}$ & 0.53 & - & - & 0.48 & 93.1 \\
\hline & & Doublet $\left(\mathrm{Fe}^{3+}\right)$ & 0.48 & 0.63 & - & 0.54 & 6.9 \\
\hline & & Magnetic Dist. & 0.34 & 0.11 & 47.2 & 0.30 & 78.7 \\
\hline \multirow{4}{*}{ Forest Reserve without GPS } & \multirow[t]{2}{*}{$300 \mathrm{~K}$} & Doublet $\left(\mathrm{Fe}^{3+}\right)$ & 0.38 & 0.60 & - & 0.61 & 19.3 \\
\hline & & Doublet $\left(\mathrm{Fe}^{2+}\right)$ & 0.88 & 0.60 & - & 0.29 & 2.0 \\
\hline & \multirow{2}{*}{$88 \mathrm{~K}$} & Magn. Compn. ${ }^{\mathrm{d}}$ & 0.54 & - & - & 0.46 & 93,7 \\
\hline & & Doublet $\left(\mathrm{Fe}^{3+}\right)$ & 0.49 & 0.60 & - & 0.61 & 6,3 \\
\hline \multirow{5}{*}{ Forest Reserve with GPS } & \multirow{3}{*}{$300 \mathrm{~K}$} & Magnetic Dist. & 0.35 & 0.11 & 47.2 & 0.30 & 78.2 \\
\hline & & Doublet $\left(\mathrm{Fe}^{3+}\right)$ & 0.39 & 0.59 & - & 0.59 & 20.9 \\
\hline & & Doublet $\left(\mathrm{Fe}^{2+}\right)$ & 0.89 & 0.62 & - & 0.28 & 1.9 \\
\hline & \multirow{2}{*}{$88 \mathrm{~K}$} & Magn. Compn. ${ }^{\mathrm{d}}$ & 0.54 & - & - & 0.48 & 95.1 \\
\hline & & Doublet $\left(\mathrm{Fe}^{3+}\right)$ & 0.46 & 0.66 & - & 0.53 & 4.9 \\
\hline \multirow{5}{*}{ Forest Reserve with $\mathrm{PO}_{4}$} & \multirow{3}{*}{$300 \mathrm{~K}$} & Magnetic Dist. & 0.38 & 0.13 & 47.8 & 0.49 & 77.9 \\
\hline & & Doublet $\left(\mathrm{Fe}^{3+}\right)$ & 0.34 & 0.61 & - & 0.51 & 21.0 \\
\hline & & Doublet $\left(\mathrm{Fe}^{2+}\right)$ & 0.80 & 0.65 & - & 0.32 & 1.1 \\
\hline & \multirow{2}{*}{$88 \mathrm{~K}$} & Magn. Compn. ${ }^{\mathrm{d}}$ & 0.51 & - & - & 0.52 & 93.1 \\
\hline & & Doublet $\left(\mathrm{Fe}^{3+}\right)$ & 0.44 & 0.60 & - & 0.55 & 6.9 \\
\hline \multirow{3}{*}{$\mathrm{PO}_{4} / \mathrm{Fe}^{3+}$} & & $300 \mathrm{~K}$ & 0.45 & 0.56 & - & 0.39 & 100 \\
\hline & & & & & & & \\
\hline & & $88 \mathrm{~K}$ & 0.52 & 0.61 & - & 0.49 & 100 \\
\hline \multirow{3}{*}{ GPS/Fe ${ }^{3+}$} & & $300 \mathrm{~K}$ & 0.40 & 0.44 & - & 0.44 & 100 \\
\hline & & & & & & & \\
\hline & & $88 \mathrm{~K}$ & 0.53 & 0.49 & - & 0.56 & 100 \\
\hline
\end{tabular}

IS = Isomer Shift; QS = Quadrupole Splitting; Bhf = Hyperfine Magnetic Field; a Relative to $\alpha$-Fe foil at room temperature; ${ }^{\mathrm{b}}$ Average value of the distribution; 'The areas were renormalized from the fitted values by considering the two apparent lines of the magnetic contributions as $1 / 6$ of a sextet or magnetic distribution; ${ }^{\mathrm{d}}$ The magnetic component was fitted as a discrete (pseudo) doublet and, hence, no hyperfine magnetic field or quadrupole splitting is ascribed to it. 